\title{
Karakteristik Fisikokimia Gelatin Tulang Ikan Patin (Pangasius sutchi) Hasil Ekstraksi Menggunakan Limbah Buah Nanas
}

\author{
Physico-chemicals Characteristic of Fish Bone Gelatin from Pangasius catfish Extracted Using Pineapple \\ Waste
Yoni Atma ${ }^{1 *}$, Hisworo Ramdhani ${ }^{1}$, Apon Zaenal Mustopa ${ }^{2}$, Mega Pertiwi ${ }^{1}$, Rizkia Maisarah ${ }^{1}$ \\ ${ }^{1}$ Program Studi Ilmu dan Teknologi Pangan, Fakultas Bioindustri, Universitas Trilogi, \\ JI. TMP. Kalibata No.1, Kalibata, Jakarta Selatan 12760, Indonesia \\ 2Pusat Penelitian Bioteknologi, Lembaga Ilmu Pengetahuan Indonesia (LIPI), Jl. Bogor Km. 46, Cibinong 16911, \\ Indonesia \\ *Email: yoniatma@trilogi.ac.id
}

Submisi: 1 November 2017; Penerimaan: 31 Januari 2018

\begin{abstract}
ABSTRAK
Tulang ikan merupakan salah satu sumber alternatif untuk produksi gelatin yang sangat potensial. Gelatin dari tulang ikan patin yang diekstrak dengan asam diketahui memiliki hasil ekstraksi yang tertinggi, kekuatan gel yang menyerupai gelatin komersial dan kadar abu yang rendah. Penelitian ini dilakukan untuk mengetahui karakteristik fisik dan kimiawi gelatin tulang ikan patin yang diekstrak dengan limbah buah nanas. Limbah buah nanas diketahui mengandung asam sitrat cukup tinggi. Penelitian dilakukan dengan dua tahap yakni ekstraksi gelatin dan analisis karakteristik fisikokimianya. Ekstraksi gelatin dilakukan dengan dua tahap yakni pre-treatment dan ekstraksi utama. Pre treatment dilakukan dengan perendaman tulang ikan dalam limbah buah nanas selama 32, 48, dan 56 jam. Ekstraksi utama dilakukan dengan perendaman dalam air hangat selama 5 jam suhu $75{ }^{\circ} \mathrm{C}$. Analisis keberadaan gelatin dengan metode SDS-PAGE diketahui gelatin berada pada kisaran berat molekul 100-150 kDa dan > 225 $\mathrm{kDa}$. Kadar hidroksiprolin gelatin yakni $10,9-16,3 \mathrm{mg} / \mathrm{g}$. Gelatin tulang ikan patin yang diekstrak dengan limbah buah nanas memiliki kekuatan gel 64,83 g.bloom, kekerasan (hardness) 4,96 g, kohesivitas (cohesiveness) 0,88, elastisitas (springiness) 1,03, kekenyalan (gumminess) 4,36, daya kunyah (chewiness) 2,78. Viskositas dan pH larutan gelatin yang diperoleh masing-masing 3,17 cP dan 4,52. Karakteristik kimiawi gelatin yang diperoleh antara lain meliputi kadar air 8,59\%, abu 0,95\%, protein kasar 47,60\% dan lemak 7,71\%. Beberapa karakteristik fisikokimia gelatin tulang ikan pada penelitian ini dapat dibandingkan dengan gelatin komersial dan gelatin tulang ikan yang lain.
\end{abstract}

Kata kunci: Ekstraksi; tulang ikan; gelatin; limbah buah nanas

\section{ABSTRACT}

Fish bones are the most potential as an alternative source for gelatin production. Pangasius catfish bone is the one of the most promising source due to its high yield of gelatin. It has similar gel strength with the commercial gelatin and has a low ash content. The aim of this research was to determine the physical and chemical characteristics of Pangasius catfish bone gelatin extracted using pineapple waste. Pineapple waste has a low pH and contains citric acid. The research was conducted in two stages i.e. gelatin extraction and physicochemical characterization. Gelatin extraction was done by pre-treatment and main extraction. Pre-treatment was done by soaking the fish bone into pineapple waste for 32, 48, and 56 hours. The main extraction was carried out by soaking fish ossein in warm water for 5 hours at $75^{\circ} \mathrm{C}$. The sodium dodecyl sulfate polyacrylamide gel electrophoresis (SDS-PAGE) was used to analyze the gelatin existence. Fish bone gelatin has molecular weight ranging from 100-150 kDa and > $225 \mathrm{kDa}$. The hydroxyproline content of gelatin was $10.9-16.3 \mathrm{mg} / \mathrm{g}$. Gelatin of Pangasius catfish bone extracted with pineapple waste has gel strength of $64.83 \mathrm{~g}$.bloom g, hardness of $4.96 \mathrm{~N}$, cohesiveness of 0.88 , springiness of 1.03 $\mathrm{mm}$, gumminess of $4.36 \mathrm{~N}$, and chewiness of $2.78 \mathrm{~N}$. Viscosity and pH of gelatin solution obtained were $3.17 \mathrm{cP}$ and 4.52 respectively. The proximate characteristics obtained were moisture $8.59 \%$, ash $0.95 \%$, crude protein $47.60 \%$ and fat $7.71 \%$. Some physicochemical parameters of gelatin resemble commercial gelatin and other fish bone gelatin. 
Keywords: Extraction; fish bone; gelatin; pineapple waste

\section{PENDAHULUAN}

Gelatin merupakan suatu polipeptida hasil hidrolisis kolagen. Sekitar sepertiga dari total protein hewani merupakan kolagen yang tersebar di kulit, tulang, jaringan ikat, tendon dan organ-organ lain. Gelatin telah diaplikasikan secara luas pada berbagai industri pangan, farmasi, kosmetik dan fotografi. Gelatin juga memiliki aktivitas antimikroba, antioksidan, dan aktivitas penghambat ACE (angiotensin converting enzyme) sebagai antihipertensi serta inhibitor enzim DPP-IV (dipeptidyl peptidase IV) untuk terapi diabetes tipe 2 (Gomez-Guillen dkk., 2011).

Produksi gelatin sebagian besar berasal dari kulit babi, kulit sapi, tulang sapi dan hanya sekitar $1 \%$ berasal dari sumber lain (Ahmad \& Benjakul, 2011). Produksi gelatin dari sumber mamalia memiliki beberapa kendala. Gelatin yang berasal dari kulit babi haram bagi komunitas Muslim dan Yahudi, sedangkan gelatin yang berasal dari sapi tidak diterima oleh beberapa komunitas Hindu. Kasus-kasus penyakit flu babi (swine influenza), sapi gila (mad cow disease) serta penyakit kuku dan mulut juga membatasi penggunaan babi dan sapi sebagai sumber utama (Nurul \& Sarbon, 2015). Oleh sebab itu diperlukan suatu sumber alternatif untuk produksi gelatin.

Limbah dari produk sampingan pengolahan ikan merupakan sumber gelatin yang paling potensial untuk dikembangkan (Karayannakidis \& Zotos, 2016). Pada industri pengolahan ikan, sekitar 75\% merupakan produk sampingan (limbah) (Mariod \& Adam, 2013). Diperkirakan hampir 7,3 juta ton limbah hasil samping pengolahan ikan dihasilkan per tahun (Karim \& Bhat, 2009). Sekitar sepertiga berat ikan berasal dari bagian kulit dan tulang ikan (Sanaei dkk., 2013). Tulang ikan seringkali dibuang dan tidak dimanfaatkan lebih lanjut. Salah satu ikan yang menghasilkan limbah tulang dalam kuantitas besar yakni tulang ikan patin. Di Indonesia saat ini ketahui produksi ikan patin nasional terus meningkat signifikan mencapai 410.684 ton per tahun (KKP, 2016). Dari nilai produksi ini diperkirakan bisa diperoleh sekitar 51.089 ton tulang ikan patin.

Penelitian (Mahmoodani dkk., 2014) menunjukkan bahwa tulang ikan patin menghasilkan gelatin dengan konsentrasi yang lebih tinggi diantara gelatin dari tulang ikan yang lain. Gelatin dari tulang ikan patin memiliki karakteristik yang menyerupai gelatin komersial. (Zhang dkk., 2011) menyatakan bahwa gelatin berbahan baku ikan-ikan yang hidup diperairan hangat memiliki karakteritik fisik yang lebih baik dibandingkan gelatin dari ikan yang hidup diperairan dingin. Karakteristik fisik penting pada gelatin meliputi kekuatan gel, tekstur dan viskositas (Badii \& Howell, 2006; Ratnasari dkk., 2013).
Gelatin dari tulang ikan patin juga memiliki kadar abu yang sesuai dengan standar (Atma, 2017). Gelatin juga dipersyaratkan harus memiliki karakteristik kimiawi yang sesuai dengan standar. Karakteristik kimiawi gelatin meliputi kadar air, abu, protein kasar, dan lemak (Amiza dkk., 2015).

Karakteristik fisikokimia gelatin dipengaruhi sumber gelatin dan metode ekstraksi (Da Trindade Alfaro dkk., 2009; Taheri dkk., 2009). Ekstraksi gelatin terdiri dari dua tahap yakni pre-treatment dan ektraksi utama. Tahapan pre-treatment menggunakan asam kuat dan atau basa kuat. Ekstraksi utama menggunakan kombinasi asam, basa dan air. Saat ini penggunaan pelarut yang aman seperti asam sitrat dan air lebih disukai oleh industri. Oleh sebab itu sudah banyak penelitian yang menggunakan asam sitrat dan air dalam tahapan ekstraksi gelatin tulang ikan (Wang \& Regenstein, 2009; Khiari dkk., 2011; Jeya Shakila dkk., 2012; Koli dkk., 2012). Asam sitrat sebenarnya terkandung dalam bahan-bahan alami seperti buahbuahan sitrus dan nanas. Pemanfaatan limbah buah nanas dalam ekstraksi gelatin dari tulang ikan selain dapat meningkatkan nilai tambah dan meminimalisir limbah-limbah agro-industri, juga dapat menurunkan bahaya atau resiko penggunaan bahan kimia. Cairan limbah buah nanas mengandung asam sitrat sebesar 0,18-0,32 \% (Hajar dkk., 2012). Cairan dari limbah buah nanas yang terdiri dari kulit, batang dan inti buah memiliki kisaran pH 3,5-4 (Ketnawa dkk., 2012). Penelitian ini mengganti larutan kimia dalam ekstraksi gelatin dengan pelarut dari limbah buah nanas. Tujuan penelitian ini mengetahui karakteristik fisikokimia gelatin tulang ikan patin hasil ekstraksi menggunakan limbah buah nanas.

\section{METODE PENELITIAN}

\section{Bahan}

Bahan utama yang digunakan dalam penelitian adalah tulang ikan patin yang diperoleh dari CV Karunia Mitra Makmur, Cikampek, Jawa Barat dan limbah buah nanas (Ananas comosus (L) Merr) yang berupa kulit dan inti buah (core steam).

\section{Persiapan Ekstrak Cair Limbah Buah Nanas}

Sisa-sisa bagian kulit dan inti buah dari nanas yang diperoleh dari pedagang di kawasan Pusat Jajanan Pancoran (PJP), Kalibata, Jakarta Selatan dibawa ke laboratorium. Bagian kulit dan inti buah ini selanjutnya dihancurkan menggunakan Blender (Homz, Cina) hingga menghasilkan pulp. Pulp kemudian disaring dan diperas menggunakan kain saring hingga didapatkan cairan limbah buah nanas. Cairan limbah buah nanas selanjutnya disterilisasi dengan autoklaf (HVE50 
Hiramaya, Jepang) pada suhu $121^{\circ} \mathrm{C}, 2 \mathrm{~atm}, 15$ menit dan disimpan pada suhu ruang sebelum digunakan sebagai larutan pengekstrak.

\section{Ekstraksi Gelatin}

Sebelum ekstraksi gelatin dilakukan, terlebih dahulu tulang ikan dibersihkan dari sisa-sisa daging yang menempel, direbus pada suhu $100{ }^{\circ} \mathrm{C}$ selama 5 menit, dikeringkan dan dihaluskan menggunakan grinder (Fomac, Taiwan). Ekstraksi gelatin dari tulang ikan patin terdiri dari 2 tahap yakni pre-treatment dan ekstraksi utama. Tahapan pre-treatment dilakukan dengan perendaman tulang ikan patin dalam cairan limbah buah nanas dengan perbandingan $1: 5(\mathrm{~m} / \mathrm{v})$ selama 32,48 , dan 56 jam. Pemisahan limbah cair buah nanas dengan tulang ikan dilakukan menggunakan sentrifugasi (Hattich, Jerman) pada kecepatan $6.000 \mathrm{rpm}$ selama 10 menit. Tulang ikan yang diperoleh dari tahapan pretreatment dinamakan ossein. Tahapan ekstraksi utama dilakukan dengan perendaman ossein dalam air pada suhu $75^{\circ} \mathrm{C}$ selama 5 jam. Ekstraksi utama dilakukan pada masing-masing perlakuan pre-treatment. Campuran ossein tulang ikan dan air dengan perbandingan 1:5 (m/v) kemudian dipisahkan dengan kertas saring. Filtrat cair yang diperoleh ditampung dalam wadah Erlenmeyer. Filtrat cair yang diperoleh ini dinamakan ekstrak cair gelatin. Gelatin cair kemudian disimpan dalam refrigerator sebelum dilakukan analisis sifat fisik. Sebagian gelatin cair juga dikeringkan menggunakan dehidrator (Excalibur, AS) pada suhu 55$60{ }^{\circ} \mathrm{C}$ sebelum analisis proksimat.

\section{Sodium Dodecyl Sulfate-Polyacrilamide Gel Electrophoresis (SDS-PAGE)}

SDS-PAGE analisis dilakukan untuk konfirmasi keberadaan gelatin tulang ikan hasil ekstraksi. SDSPAGE dilakukan dengan sistem diskontinu buffer Tris/HCl/glisin. Ekstrak cair gelatin diencerkan dengan buffer yang mengandung Tris- $\mathrm{HCl} 15 \% \mathrm{pH} 6,8$ yang terdiri dari $5 \%$ SDS, $20 \%$ gliserol, dan $10 \%$ bmerkaptoetanol pada rasio 1:1 menggunakan $4 \%$ stacking ge/ dan $10 \%$ reso/ving gel. Sampel kemudian di running pada perangkat elektroforesis (ATTO Page Run Ace, Jepang) dengan prinsip pergerakan protein berdasarkan berat molekul dengan bantuan arus listrik. Keberadaan protein gelatin diperjelas dengan perendaman gel pada larutan pewarna (staining). Keberadaan gelatin tulang ikan ditetapkan berdasarkan pita-pita marker protein (Promega, AS) yang telah diketahui berat molekulnya. Protein marker yang digunakan memiliki berat molekul 225, 150, 100, 75, 50, 35, 25, 15, dan $10 \mathrm{kDa}$.

\section{Kadar Hidroksiprolin}

Kadar hidroksiprolin digunakan untuk menentukan konsentrasi gelatin tulang ikan patin yang diperoleh. Pengukuran kadar hidroksiprolin dilakukan sesuai dengan metode Bergman \& Loxley (1963), dan sebelumnya telah diterapkan oleh (Koli dkk., 2012) dengan beberapa modifikasi. Sampel cair gelatin dihidrolisis dengan $12 \mathrm{~N} \mathrm{HCl}$ pada suhu $120^{\circ} \mathrm{C}$ selama 3 jam. Kemudian sampel hasil hidrolisis disaring menggunakan kertas Whatman No.4. Filtrat sampel kemudian dimasukkan kedalam plate reader dan ditambahkan reagen kloramin yang mengandung 1,4\% (w/v) kloroamin $\mathrm{T}$ dan buffer oksidan dengan rasio $1: 10(\mathrm{v} / \mathrm{v})$. Selanjutnya campuran diinkubasi selama 5 menit pada suhu ruang. Setelah itu ditambahkan reagen p-dimethylaminobenzaldehyde (DMAB) yang mengandung $10 \%$ DMAB konsentrat dan $60 \%(\mathrm{w} / \mathrm{v})$ larutan asam perklorat/isopropanol dengan perbandingan 1:1 (v/v). Campuran sampel dengan reagen kit (Biovision, AS) ini kemudian divortex dan diinkubasi pada suhu $60{ }^{\circ} \mathrm{C}$ selama 90 menit. Campuran sampel dan larutan reagen selanjutnya didinginkan selama 2-3 menit menggunakan air mengalir. Absorbansi campuran sampel diukur menggunakan spektrofotometer (Thermo Multiskan, AS) pada panjang gelombang $540 \mathrm{~nm}$. Hidroksiprolin (Biovision, AS) digunakan sebagai larutan standar dengan konsentrasi $0,2-1 \mu \mathrm{g} / \mathrm{mL}$.

\section{Analisis Karakteristik Fisikokimia}

\section{Kekuatan gel}

Analisis kekuatan gel mengacu pada Metode British Standard 757:1975 (GMIA, 2013). Cairan gelatin $(6,67 \% ; \mathrm{m} / \mathrm{v})$ tulang ikan patin dimasukkan ke dalam botol bloom standar (bloom jar). Kemudian dipanaskan pada suhu $60^{\circ} \mathrm{C}$ selama 15 menit untuk melarutkan gelatin dan mendapatkan larutan gelatin yang homogen. Setelah itu larutan gelatin dimasukkan kedalam refrigerator selama $16-18$ jam pada suhu kisaran suhu $4{ }^{\circ} \mathrm{C}$. Kekuatan gel ditentukan menggunakan alat Texture Analyzer (CT3 Brookfield, AS) yang diatur dengan load cell $\pm 5 \mathrm{~kg}$, cross-head speed $1 \mathrm{~mm} / \mathrm{s}$ dan diameter $5 \mathrm{~mm}$. Botol bloom yang berisi larutan gelatin tersebut kemudian ditempatkan ditengah dan selanjutnya penetrasi probe dibiarkan hingga kedalaman $4 \mathrm{~mm}$. Selajutnya data kekuatan gel akan tercatat melalui perangkat komputer yang dihubungkan dengan alat. Pengukuran dilakukan dengan 3 kali ulangan.

\section{Profil Tekstur}

Persiapan analisis profil tekstur dilakuan dengan cara yang sama dengan analisis kekuatan gel. Hanya saja setelah didinginkan dalam refrigerator, kemudian larutan sampel dibiarkan pada suhu ruang dingin (15 ${ }^{\circ} \mathrm{C}$ ), selama 30 menit. Profil tekstur dianalisis dengan alat Texture Analyzer (CT3 Brookfield, AS). Gel ditekan dengan lempengan aluminium hingga terjadi deformasi sebesar 25\% pada kecepatan $1 \mathrm{~mm} / \mathrm{s}$ (Mahmoodani dkk., 2014; Sanaei dkk., 2013). Pengukuran dilakukan dengan 3 kali ulangan. 


\section{Viskositas}

Viskositas diukur sesuai dengan metode yang telah digunakan oleh Jeya Shakila dkk., (2012). Cairan gelatin tulang ikan diukur nilai viskositas atau kekentalan (CP) dengan Brookfield Digital Viscometer (Model LV Brookfield, Inggris) menggunakan spindle SC4-31 kecepatan $60 \mathrm{rpm}$ pada suhu ruang $\left(27^{\circ} \mathrm{C}\right)$. Pengukuran dilakukan dengan 3 kali ulangan.

\section{pH Gelatin}

Gelatin tulang ikan dalam bentuk cair yang diperoleh dari hasil ekstraksi dipanaskan pada suhu $60^{\circ} \mathrm{C}$ dan diaduk menggunakan batang pengaduk kecepatan 3 rpm selama 30 menit. Pemanasan dan pengadukan dilakukan menggunakan Magnetic Stirrer (Stuart, Inggris). Setelah itu, cairan gelatin dibiarkan dingin pada suhu ruang. $\mathrm{pH}$ gelatin diukur menggunakan elektroda kaca pH meter (Agilent, AS) yang sebelumnya dikalibrasi dengan larutan buffer $\mathrm{pH}$ 4, 7, dan 12.

\section{Analisis Proksimat}

Analisis proksimat dilakukan sesuai dengan prosedur yang ditetapkan oleh AOAC (association of analytical communities). Analisis proksimat meliputi kadar air dengan metode oven, protein kasar dengan metode Kjeldahl dimana faktor konversi N (nitrogen) gelatin 5,4, analisis lemak dengan metode soxhlet, kadar abu dengan metode pengabuan kering pada suhu sekitar $600{ }^{\circ} \mathrm{C}$ dan kadar karbohidat kasar dengan rumus by different.

\section{HASIL DAN PEMBAHASAN}

\section{Gelatin Tulang Ikan Hasil Ekstraksi Limbah Buah Nanas}

Ekstraksi gelatin dikelompokkan menjadi 2 metode proses yaitu ekstraksi asam dan ekstraksi basa. Kedua metode memiliki 2 tahapan yaitu pre-treatment dan ekstraksi utama. Ekstraksi proses asam dilakukan menggunakan medium asam pada tahap ekstraksi utama atau menggunakan asam pada tahap pretreatment. Penggunaan asam sitrat sebagai pelarut dalam tahapan pre-treatment ekstraksi gelatin lebih baik dibandingkan asam organik lainnya seperti yang telah dijelaskan oleh Mariod \& Adam (2013) dan Mariod dkk. (2011). Salah satu sumber alami yang mengandung asam sitrat cukup tinggi adalah limbah buah nanas (Hajar dkk., 2012). Asam sitrat merupakan asam organik yang paling berperan terhadap tingkat keasaman limbah buah nanas. Kandungan asam sitrat pada limbah buah nanas sekitar 2,18 g per liternya (Abdullah \& Mat, 2008).

Pada penelitian ini gelatin berhasil diekstrak dari tulang ikan patin menggunakan limbah buah nanas pada kondisi pre-treatment selama 32, 48, dan 56 jam dengan ekstraksi utama selama 5 jam pada suhu $75^{\circ} \mathrm{C}$. Hasil analisis konfirmasi dengan SDS-PAGE menunjukkan bahwa pola pita gelatin hasil ekstraksi menyerupai pola-pola pita protein gelatin dari tulang ikan dari penelitian-penelitian sebelumnya. SDS-PAGE merupakan metode analisis protein secara kualitatif yang paling banyak digunakan. Metode SDS-PAGE telah digunakan untuk konfirmasi keberhasilan tahapan ekstraksi pada ekstraksi gelatin dari tulang ikan nila (Lates niloticus) (Muyonga dkk., 2004), beloso (Saurida tumbi) (Taheri dkk., 2009), king weakfish (Macrodon ancylodon) (Da Trindade Alfaro dkk., 2009), channel catfish (Ictalurus punctatus) (Liu dkk., 2009), koan (Ctenopharyngodon idella) (Zhang dkk., 2011), kakap merah (Lutjanus campechanus), kerapu (Epinephelus chlorostigma) (Jeya Shakila dkk., 2012) dan patin (Mahmoodani dkk., 2014).

Pada penelitian ini pita protein dari tulang ikan patin hasil ekstraksi menggunakan limbah buah teridentifikasi pada kisaran berat molekul $>225 \mathrm{kDa}$, $\sim 150 \mathrm{kDa}, \sim 100 \mathrm{kDa}$ dan $<75 \mathrm{kDa}$. Penelitian Mahmoodani dkk., (2014) menunjukkan pita protein gelatin tulang ikan patin hasil ekstraksi menggunakan asam klorida dan sodium hidroksida berada pada berat molekul $200 \mathrm{kDa}$ untuk ikatan $\beta$ dan $116 \mathrm{kDa}$ untuk a1 dan a2. Gelatin dari tulang ikan yang lain juga teridentifikasi pada kisaran berat molekul $100 \mathrm{kDa}$ (Liu dkk., 2009), 100-150 kDa (Muyonga dkk., 2004), 97$130 \mathrm{kDa}$ dan $\geq 200 \mathrm{kDa}$ (Taheri dkk., 2009; Da Trindade Alfaro dkk., 2009; Zhang dkk., 2011; Jeya Shakila dkk., 2012). Pada penelitian ini pola pita protein gelatin tulang ikan teridentifikasi pada kisaran berat molekul $225 \mathrm{kDa}, 150 \mathrm{kDa}$ dan $100 \mathrm{kDa}$. Gelatin yang berada pada kisaran berat molekul yang lebih kecil dari $75 \mathrm{kDa}$ merupakan bentuk protein gelatin yang terdegradasi. Da Trindade Alfaro dkk. (2009) menyatakan bahwa keberadaan pita sebaran protein gelatin di area berat molekul lebih rendah mengindikasikan terdegradasinya gelatin atau kolagen selama proses atau tahapan ekstraksi.

Tabel 1. Kadar hidroksiprolin gelatin tulang ikan patin hasil ekstraksi limbah buah nanas

\begin{tabular}{llc}
\hline $\begin{array}{l}\text { Sumber } \\
\text { gelatin }\end{array}$ & $\begin{array}{c}\text { Metode ekstraksi } \\
\text { dengan limbah nanas }\end{array}$ & $\begin{array}{c}\text { Kadar } \\
\text { hidroksiprolin } \\
(\mathrm{mg} / \mathrm{g})\end{array}$ \\
\hline Tulang & 32 jam pre-treatment & 10,9 \\
ikan patin & 48 jam pre-treatment & 11,9 \\
& 56 jam pre-treatment & 16,3 \\
\hline
\end{tabular}

Hidroksiprolin merupakan satu diantara asam amino-asam amino penyusun gelatin. Keberadaan hidroksiprolin pada sekuen asam amino penyusun gelatin memberikan keunikan tersendiri, karena persentasenya yang cukup tinggi sehingga dapat digunakan untuk menghitung hasil ekstraksi (extraction yield). Pada penelitian ini diperoleh gelatin tulang ikan dengan kadar hidroksiprolin 10,9-16,3 mg/g (Tabel 1). Kadar hidroksiprolin pada gelatin tulang ikan patin yakni 59,7 mg/g (Mahmoodani dkk., 2014). Kadar 
hidroksiprolin yang tinggi akan menghasilkan gelatin dengan kekuatan gel yang tinggi pula (Wang \& Regenstein, 2009). Analisis karakteristik fisikokimia dilakukan pada hasil perlakuan terbaik.

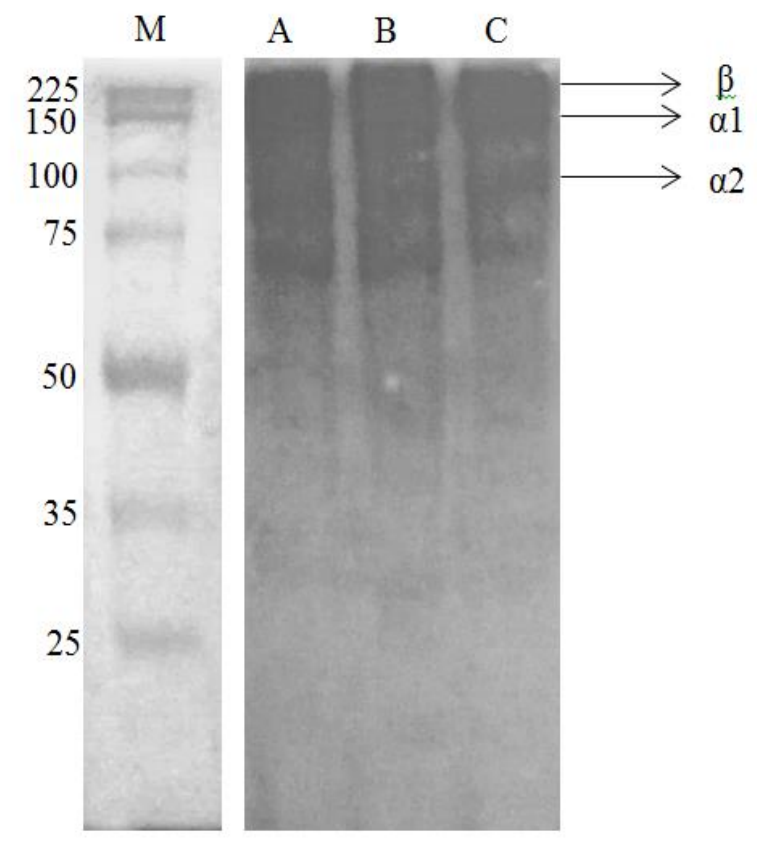

Gambar 1. Distribusi berat molekul gelatin dari tulang ikan patin hasil ekstraksi menggunakan limbah buah nanas. Gelatin yang diekstraksi dengan perlakuan pre-treatment 32 jam (A), 48 jam (B) dan 56 jam (C). M = protein marker

\section{Kekuatan Gel}

Analisis karakteristik fisikokimia dilakukan pada gelatin tulang ikan yang memiliki kadar hidroksiprolin tertinggi. Parameter kualitas fisik gelatin yang utama adalah kekuatan gel. Gelatin komersial yang memiliki kekuatan gel tertinggi lebih dipilih untuk digunakan industri. Pada penelitian ini diperoleh kekuatan gel dari gelatin tulang ikan patin sebesar 64,83 g.bloom (Gambar 2). Nilai kekuatan gel gelatin pada penelitian ini masih lebih rendah dibandingkan kekuatan gel gelatin tulang ikan lainnya. Nilai kekuatan gel yang dihasilkan pada penelitian ini masih sesuai dengan standar kekuatan gel gelatin yang ditetapkan oleh Gelatin Manufacturers

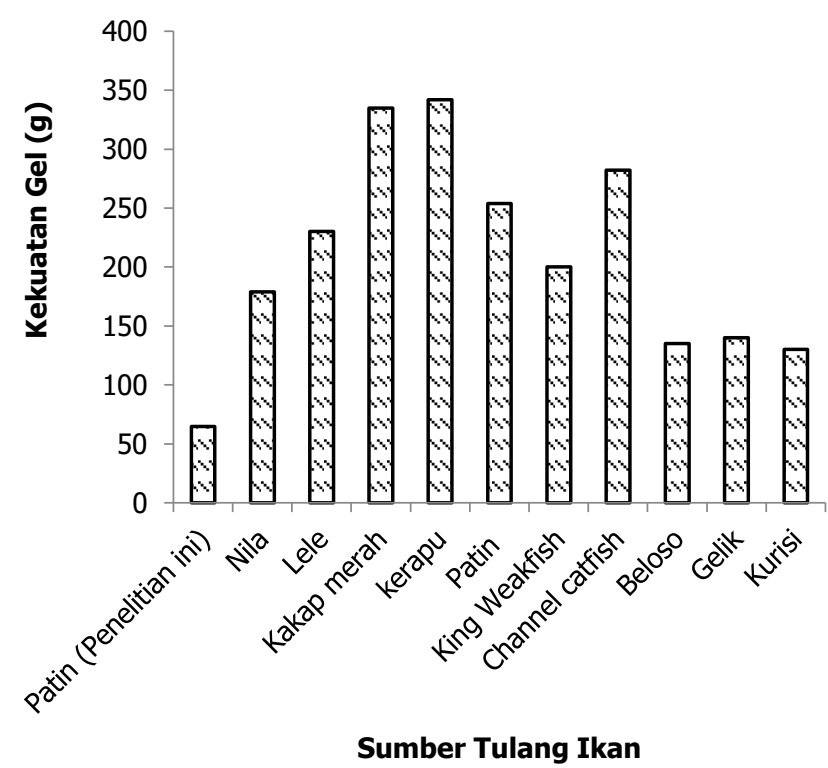

Gambar 2. Perbandingan kekuatan gel (g) gelatin tulang ikan patin hasil ekstraksi menggunakan limbah nanas dengan gelatin dari tulang ikan lainnya seperti ikan nila (Muyonga dkk., 2004), lele (Sanaei dkk., 2013), kakap merah dan kerapu (Jeya Shakila dkk., 2012), patin (Mahmoodani dkk., 2014), king weakfish (Da Trindade Alfaro dkk., 2009), channel catfish (Liu dkk., 2009), beloso (Taheri dkk., 2009), gelik dan kurisi (Koli dkk., 2012).

Institute of America (GMIA). GMIA menentapkan rentang standar kekuatan gel gelatin yakni pada kisaran 50-300 g.bloom (GMIA, 2013).

Kekuatan gel disebabkan oleh interaksi molekul air dengan ikatan hidrogen membentuk struktur tiga dimensi yang stabil. Kekuatan gel gelatin yang berasal dari ikan lebih rendah dibandingkan gelatin yang berasal dari hewan mamalia. Gelatin komersial memiliki kekuatan gel tertinggi sebesar 466,4 g.bloom (Chandra \& Shamasundar, 2015). Menurut Sanaei dkk. (2013) kekuatan gel dipengaruhi oleh komposisi asam amino prolin dan hidroksiprolin gelatin. Selain itu, kekuatan gel juga dipengaruhi oleh metode ekstraksi dan berat molekul gelatin (Nurul \& Sarbon, 2015; Hafidz \& Yaakob, 2011).

Tabel 2. Nilai profil tekstur, viskositas, dan $\mathrm{pH}$ gelatin tulang ikan patin hasil ekstraksi menggunakan limbah buah nanas dibandingkan dengan gelatin komersial dan gelatin tulang ikan yang lain

\begin{tabular}{cccc}
\hline Profil tekstur & Penelitian ini & Gelatin komersial* & $\begin{array}{c}\text { Gelatin tulang ikan patin dan } \\
\text { beloso** }\end{array}$ \\
\hline Kekerasan (hardness) & 4,96 & 14,4 & 5,34 \\
Kohesivitas (cohesiveness) & 0,88 & 0,91 & 0,92 \\
Elastisitas (springiness) & 1,03 & 0,94 & 0,95 \\
Kekenyalan (gumminess) & 4,36 & 13,17 & 4,91 \\
Daya kunyah (Chewiness) & 2,78 & 12,45 & 4,67 \\
Viskositas (cP) & 3,17 & 3,90 & 3,10 \\
pH & 4,52 & 6,18 & 4,15 \\
\hline
\end{tabular}

* Chandra \& Shamasundar, (2015)

** Mahmoodani dkk., (2014); Taheri dkk., (2009) 


\section{Profil Tekstur}

Nilai kekuatan gel belum menggambarkan karakteristik tekstur dari gelatin, sehingga perlu dilakukan analisis profil tekstur. Profil tekstur gelatin meliputi kekerasan (hardness), kohesivitas (cohesiveness), elastisitas (springiness), kekenyalan (gumminess) dan daya kunyah (chewiness). Kekerasan merupakan kekuatan dari struktur gel akibat dari pemampatan (compression) yang diberikan. Kekerasan gelatin tulang ikan patin yang diekstrak dengan limbah nanas lebih rendah dibandingkan gelatin tulang ikan lainnya dan gelatin komersial. Kekerasan gelatin dipengaruhi kekuatan gel (Chandra \& Shamasundar, 2015). Muyonga dkk. (2004) menyatakan bahwa kekuatan gel gelatin dipengaruhi oleh konsentrasi gelatin, berat molekul dan bentuk ikatan serta komposisi asam amino. Pada penelitian ini diperoleh gelatin yang didominasi dengan ikatan beta dan alfa meskipun umumnya gelatin tulang ikan didominasi ikatan alfa (Taheri dkk., 2009; Da Trindade Alfaro dkk., 2009). Asam amino hidroksiprolin dan prolin yang tinggi juga akan meningkatkan kekuatan gel. Pada penelitian ini kadar hidroksiprolin pada gelatin yang diperoleh lebih rendah dibandingkan gelatin tulang ikan patin (Mahmoodani dkk., 2014) dan gelatin komersial (Chandra \& Shamasundar, 2015).

Kohesivitas, elastisitas, kekenyalan dan daya kunyah merupakan bagian penting dari karakteristik tekstur gelatin. Kohesivitas menunjukkan kekuatan tarikmenarik antar molekul gel untuk mempertahankan bentuknya ketika diberi gaya dari luar. Elastisitas adalah kecenderungan gel untuk kembali kebentuk semula setelah mengalami deformasi. Elastisitas gelatin menggambarkan ketinggian gel setelah gigitan pertama sebelum gigitan kedua. Kekenyalan menunjukkan energi yang dibutuhkan untuk menghancurkan makanan semipadat. Kekenyalan merupakan interpretasi dari kekerasan dan nilai kohesivitas. Semakin tinggi kekerasan dan nilai kohesivitas maka kekenyalan gel juga akan semakin tinggi. Daya kunyah menunjukkan energi yang dibutuhkan untuk mengunyah makanan padat. Daya kunyah diperoleh dari interpretasi kekenyalan dan elastisitas (Wangtueai \& Noomhorm, 2009).

Kohesivitas dan kekenyalan gelatin pada penelitian ini lebih rendah dibandingkan gelatin tulang ikan yang lain dan gelatin komersial. Nilai kohesivitas akan meningkat dengan peningkatan konsentrasi gelatin.
Namun, nilai kohesivitas akan menurun jika konsentrasi gelatin melewati ambang batas maksimal. Kohesivitas larutan gelatin mencapai maksimal pada konsentrasi 24 $\mathrm{g} / \mathrm{L}$ (Rahman \& Al-Mahrouqi, 2009). Elastisitas gelatin pada penelitian ini dapat dibandingkan dengan gelatin tulang ikan yang lain dan gelatin komersial. Namun nilai daya kunyah gelatin pada penelitian ini lebih rendah dibandingkan gelatin tulang ikan lain dan gelatin komersial. Daya kunyah merupakan nilai yang paling sulit untuk diukur ketepatannya, karena mengunyah meliputi proses-proses memampatkan, memotong, merobek, menusuk, menggiling dan diikuti dengan pelumasan menggunakan kelanjar saliva yang cukup pada suhu tubuh (Bhale, 2004).

\section{Viskositas dan pH}

Viskositas merupakan karakteristik fisik kedua yang mempengaruhi kualitas gelatin setelah kekuatan gel. Viskositas gelatin berperan penting dalam membentuk dan menjaga stabilitas sistem emulsi (Mahmoodani dkk., 2014). Menurut Taheri dkk. (2009) viskositas gelatin dipengaruhi oleh distribusi berat molekulnya. Penelitian Mahmoodani dkk. (2014) mendapatkan gelatin tulang ikan patin yang memiliki berat molekul dominan sebesar $\sim 120 \mathrm{kDa}$. Penelitian (Jeya Shakila dkk., 2012) mendapatkan gelatin tulang ikan kakap merah dan kerapu yang memiliki berat molekul dominan >200 kDa. Viskositas gelatin tulang ikan kakap merah dan kerapu 13,3-18,5 cP, sedangkan viskositas gelatin tulang ikan patin 3,1 cP. Standar viskositas gelatin yang dipersyaratkan adalah 1,5-7 cP (GMIA, 2013). Penelitian ini mendapatkan gelatin dengan viskositas dan nilai derajat keasamaan $(\mathrm{pH})$ yang sesuai dengan standar dan dapat dibandingkan dengan gelatin komersial serta gelatin tulang ikan lainnya. Nilai derajat keasaman $(\mathrm{pH})$ gelatin tulang ikan patin yang diekstrak dengan limbah buah nanas yakni 4,52 (Tabel 2). Gelatine Manufacturing Institute of America (GMIA) menetapkan standar $\mathrm{pH}$ gelatin pada rentang 3,8-5,5. Studi sebelumnya melaporkan gelatin tulang ikan kakap merah dan kerapu masing-masing memiliki pH 4,6 dan 4,31(Jeya Shakila dkk., 2012). pH gelatin tulang ikan gelik dan kurisi masing-masing 4,62 dan 4,80 (Koli dkk., 2012). pH gelatin tulang ikan beloso adalah 4,15 (Taheri dkk., 2009).

\section{Kadar Proksimat}

Parameter kualitas kimia gelatin yang ditetapkan oleh Gelatin Manufacturers Institute of America (GMIA) dan Standar Nasional Indonesia (SNI) yakni kadar air

Tabel 3. Karakteristik kimia gelatin tulang ikan patin yang diekstrak menggunakan limbah buah nanas

\begin{tabular}{lcccc}
\hline \multicolumn{1}{c}{ Parameter kimiawi } & $\begin{array}{c}\text { Gelatin tulang ikan patin } \\
\text { (penelitian ini) }\end{array}$ & Gelatin Tulang ikan* & $\begin{array}{c}\text { Gelatin } \\
\text { komersial }\end{array}$ & Standar GMIA/SNI \\
\hline Kadar air (\%) & 8,59 & 10,33 & 9,56 & Maks. 16 \\
Kadar abu (\%) & 0,95 & 2,7 & 0,1 & Maks. 3,2 \\
Protein kasar (\%) & 47,60 & 82,5 & - & - \\
Lemak (\%) & 7,71 & 0,52 & - & -0 \\
\hline
\end{tabular}

\footnotetext{
${ }^{*}$ Gelatin tulang ikan kakap merah
} 
dan kadar abu. Kadar protein yang tinggi pada gelatin tentu diharapkan. Kadar lemak dan karbohidrat belum ditetapkan, namun gelatin dengan kandungan lemak yang rendah memiliki kualitas yang lebih baik (Shyni dkk., 2014).

Pada penelitian ini diperoleh kadar air dan abu yang sesuai dengan standar. Namun, kadar protein kasar gelatin tulang ikan patin yang diekstrak dengan limbah buah nanas lebih rendah dibandingkan gelatin komersial dan gelatin tulang ikan lainnya. Kandungan protein suatu gelatin dipengaruhi oleh larutan ekstraksi yang digunakan. Pada penelitian ini larutan yang digunakan adalah limbah buah nanas yang memiliki keasaman lebih rendah dibandingkan pelarut kimiawi yang lain. Ekstraksi gelatin baik dari tulang ikan ataupun dari hewan mamalia biasa menggunakan asam kuat dan atau basa kuat. Tahapan demineralisasi dalam ekstraksi gelatin dari tulang ikan menjadi penting karena akan melepaskan semua mineral yang terikat pada protein (Fatimah \& Jannah, 2008). Kadar lemak gelatin tulang ikan pada penelitian ini juga lebih tinggi dibandingkan kadar lemak gelatin tulang ikan yang lain dan gelatin komersial. Kandungan lemak yang tinggi dapat disebabkan oleh sisa lemak ikan dan tulang ikan yang masih menempel dan sedikit lemak dari limbah nanas. Tulang ikan patin masih mengandung lemak 8,7\% (Mahmoodani dkk., 2014). Limbah nanas mengandung lemak sebesar 0,15\% (Abdullah \& Mat, 2017). Karakteristik kimia gelatin dari tulang ikan patin yang diekstrak menggunakan limbah buah nanas disajikan pada Tabel 3.

\section{KESIMPULAN}

Gelatin tulang ikan patin yang diekstrak dengan limbah buah nanas memiliki kekuatan gel 64,83 g.bloom, kekerasan 4,96, kohesivitas 0,88 , elastisitas 1,03 , kekenyalan 4,36 , dan daya kunyah 2,78 . Viskositas dan $\mathrm{pH}$ larutan gelatin yang diperoleh masing-masing 3,17 cP dan 4,52. Karakteristik kimiawi gelatin antara lain meliputi kadar air 8,59\%, abu 0,95\%, protein kasar $47,60 \%$, dan lemak $7,71 \%$. Beberapa karakteristik fisikokimia gelatin tulang ikan pada penelitian ini dapat dibandingkan dengan gelatin komersial dan gelatin tulang ikan yang lain.

\section{UCAPAN TERIMA KASIH}

Penulis mengucapkan terima kasih kepada Direktorat Riset dan Pengabdian Masyarakat (DRPM) Kementrian Riset dan Pendidikan Tinggi (RISTEKDIKTI) dan Indonesian Toray Science Foundation (ITSF) yang telah mendanai penelitian ini.

\section{DAFTAR PUSTAKA}

Abdullah \& Mat, H. (2017). The Characteristic of pineapple waste from canning industry. Advanced Science Letters,
23(6), 5691-5693.

Abdullah, A., \& Mat, H. (2008). Characterisation of Solid and Liquid Pineapple Waste. Reaktor, 12(1), 48-52. http://doi.org/10.14710/reaktor.12.1.48-52.

Ahmad, M., \& Benjakul, S. (2011). Characteristics of gelatin from the skin of unicorn leatherjacket (Aluterus monoceros) as influenced by acid pretreatment and extraction time. Food Hydrocolloids, 25(3), 381-388. http://doi.org/10.1016/j.foodhyd.2010.07.004.

Amiza, M. A., Wan Maizatul Shima, W. M., Nor Hayati, I., \& Nizaha Juhaida, M. (2015). Optimization of gelatin extraction conditions from Cobia (Rachycentron canadum) skin and its physicochemical characteristics as compared to bovine gelatin. International Food Research Journal, 22(1), 213-224.

Atma, Y. (2017). Amino acid and proximate composition of fish bone gelatin from different warm-water species: A comparative study. IOP Conf. Ser.: Earth Environ. Sci., 58(012008), 6-11. http://doi.org/10.1088/1755-1315/5.

Badii, F., \& Howell, N. K. (2006). Fish gelatin: Structure, gelling properties and interaction with egg albumen proteins. Food Hydrocolloids, 20(5), 630-640. http://doi.org/10.1016/j.foodhyd.2005.06.006.

Bergman, I., \& Loxley, R. (1963). Two Improved and Simplified Methods for the Spectrophotometric Determination of Hydroxyproline. Analytical Chemistry, 35(12), 1961-1965. http://doi.org/10.1021/ac60205a053.

Bhale, S. D. (2004). Effect of Ohmic Heating on Color, Rehydration and Textural Characteristics of Fresh Carrot Cubes [thesis]. Department of Biological \& Agricultural Engineering, B.Tech, Mahatma Phule Agricultural University, India.

Chandra, M. V., \& Shamasundar, B. A. (2015). Texture profile analysis and functional properties of gelatin from the skin of three species of fresh water fish. International Journal of Food Properties, 18(3), 572-584. http://doi.org/10.1080/10942912.2013.845787.

Da Trindade Alfaro, A., Simões Da Costa, C., Graciano Fonseca, G., \& Prentice, C. (2009). Effect of extraction parameters on the properties of gelatin from king weakfish (Macrodon ancylodon) Bones. Food Science and Technology International, 15(6), 553-562. http://doi.org/10.1177/1082013209352921.

Fatimah, D., Jannah, A. (2009). Efektivitas Penggunaan Asam Sitrat Dalam Pembuatan Gelatin Tulang Ikan Bandeng (Chanos-Chanos Forskal). Alchemy, 1 (1): 7-15

GMIA. (2013). Standard testing methods for edible gelatin, (July), 27. http://doi.org/10.1021/ja02055a023.

Gomez-Guillen, M. C., Gimenez, B., Lopez-Caballero, M. E., \& Montero, M. P. (2011). Functional and bioactive properties of collagen and gelatin from alternative sources: A review. Food Hydrocolloids, 25(8), 1813-1827. http://doi.org/10.1016/j.foodhyd.2011.02.007.

Hafidz, R., \& Yaakob, C. (2011). Chemical and functional properties of bovine and porcine skin gelatin. International Food Research Journal, 817, 813-817.

Hajar, N., Zainal, S., Nadzirah, K. Z., Roha, A. M. S., Atikah, O., \& Elida, T. Z. M. T. (2012). Physicochemical Properties Analysis of Three Indexes Pineapple (Ananas Comosus) Peel Extract Variety N36. APCBEE Procedia, 4, 115-121. http://doi.org/10.1016/j.apcbee.2012.11.020.

Jeya Shakila, R., Jeevithan, E., Varatharajakumar, A., Jeyasekaran, G., \& Sukumar, D. (2012). Functional characterization of gelatin extracted from bones of red 
snapper and grouper in comparison with mammalian gelatin. LWT - Food Science and Technology, 48(1), 30-36. http://doi.org/10.1016/j.lwt.2012.03.007.

Karayannakidis, P. D., \& Zotos, A. (2016). Fish Processing ByProducts as a Potential Source of Gelatin: A Review. Journal of Aquatic Food Product Technology, 25(1), 65-92. http://doi.org/10.1080/10498850.2013.827767.

Karim, A. A., \& Bhat, R. (2009). Fish gelatin: properties, challenges, and prospects as an alternative to mammalian gelatins. Food Hydrocolloids, 23(3), 563-576. http://doi.org/10.1016/j.foodhyd.2008.07.002.

Ketnawa, S., Chaiwut, P., \& Rawdkuen, S. (2012). Pineapple wastes: A potential source for bromelain extraction. Food and Bioproducts Processing, 90(3), 385-391. http://doi.org/10.1016/j.fbp.2011.12.006.

Khiari, Z., Rico, D., Martin-Diana, A. B., \& Barry-Ryan, C. (2011). The extraction of gelatine from mackerel (Scomber scombrus) heads with the use of different organic acids. Journal of FisheriesSciences.Com, 5(1), 52-63. http://doi.org/10.3153/jfscom.2011007.

KKP. (2016). Performance Report of the Ministry of Marine Affairs and Fisheries Year 2015. Kementerian Kelautan Dan Perikanan, 1-57.

Koli, J. M., Basu, S., Nayak, B. B., Patange, S. B., Pagarkar, A. U., \& Gudipati, V. (2012). Functional characteristics of gelatin extracted from skin and bone of Tiger-toothed croaker (Otolithes ruber) and Pink perch (Nemipterus japonicus). Food and Bioproducts Processing, 90(3), 555562. http://doi.org/10.1016/j.fbp.2011.08.001.

Liu, H. Y., Han, J., \& Guo, S. D. (2009). Characteristics of the gelatin extracted from Channel Catfish (Ictalurus Punctatus) head bones. LWT - Food Science and Technology, 42(2), 540-544. http://doi.org/10.1016/j.lwt.2008.07.013.

Mahmoodani, F., Ardekani, V. S., See, S. F., Yusop, S. M., \& Babji, A. S. (2014). Optimization and physical properties of gelatin extracted from pangasius catfish (Pangasius sutchi) bone. Journal of Food Science and Technology, 51(11), 3104-3113. http://doi.org/10.1007/s13197-012-0816-7.

Mariod, A. A., \& Adam, H. F. (2013). Review: Gelatin, source, extraction and industrial applications. Acta Scientiarum Polonorum, Technologia Alimentaria, 12(2), 135-147. http://doi.org/10.1002/adma.200802244.

Mariod A.A., Abdel-Wahab S.I., Ibrahim M.Y., M. S., \& Abd Elgadir M., A. N. M. (2011). Preparation and Characterization of Gelatins from Two Sudanese Edible Insects Preparation and Characterization of Gelatins from Two Sudanese Edible Insects. J. Food Sci. Eng., 1(September 2015), 45-55.

Muyonga, J. H., Cole, C. G. B., \& Duodu, K. G. (2004). Extraction and physico-chemical characterisation of Nile perch (Lates niloticus) skin and bone gelatin. Food Hydrocolloids, 18(4), 581-592. http://doi.org/10.1016/j.foodhyd.2003.08.009.

Nurul, A. G., \& Sarbon, N. M. (2015). Effects of pH on functional, rheological and structural properties of eel (Monopterus sp.) skin gelatin compared to bovine gelatin. International Food Research Journal, 22(2), 572-583.

Rahman, M. S., \& Al-Mahrouqi, A. I. (2009). Instrumental texture profile analysis of gelatin gel extracted from grouper skin and commercial (bovine and porcine) gelatin gels. International Journal of Food Sciences and Nutrition, 6OSUPPL. 7), http://doi.org/10.1080/09637480902984414.
Ratnasari, I., Yuwono, S. S., Nusyam, H., \& Widjanarko, S. B. (2013). Extraction and characterization of gelatin from different fresh water fishes as alternative sources of gelatin. International Food Research Journal, 20(6), 3085-3091.

Sanaei, A. V., Mahmoodani, F., See, S. F., Yusop, S. M., \& Babji, A. S. (2013). Optimization of gelatin extraction and physico-chemical properties of catfish (Clarias gariepinus) bone gelatin. International Food Research Journal, 20(1), 423-430.

Shyni, K., Hema, G. S., Ninan, G., Mathew, S., Joshy, C. G., \& Lakshmanan, P. T. (2014). Isolation and characterization of gelatin from the skins of skipjack tuna (katsuwonus pelamis), dog shark (scoliodon sorrakowah), and rohu (labeo rohita). Food Hydrocolloids, 39, 68-76. http://doi.org/10.1016/j.foodhyd.2013.12.008.

Taheri, A., Abedian Kenari, A. M., Gildberg, A., \& Behnam, S. (2009). Extraction and physicochemical characterization of greater lizardfish (Saurida tumbil) skin and bone gelatin. Journal of Food Science, 74(3), 160-165. http://doi.org/10.1111/j.1750-3841.2009.01106.x.

Wang, Y., \& Regenstein, J. M. (2009). Effect of EDTA, $\mathrm{HCl}$, and citric acid on Ca salt removal from Asian (silver) carp scales prior to gelatin extraction. Journal of Food Science, 74(6), 426-431. http://doi.org/10.1111/j.17503841.2009.01202.x.

Wangtueai, S., \& Noomhorm, A. (2009). Processing optimization and characterization of gelatin from lizardfish (Saurida spp.) scales. LWT - Food Science and Technology, 42(4), 825-834. http://doi.org/10.1016/j.lwt.2008.11.014.

Zhang, F., Xu, S., \& Wang, Z. (2011). Pre-treatment optimization and properties of gelatin from freshwater fish scales. Food and Bioproducts Processing, 89(3), 185-193. http://doi.org/10.1016/j.fbp.2010.05.003. 